\title{
EVALUATING MOST PROBABLE NUMBER METHOD TO COUNT AND ISOLATE VIABLE METHYLOTROPHS
}

\author{
S. Kashyap*
}

National Bureau of Agriculturally Important Microorganisms (ICAR), Kusmaur, Kaithauli, Mau Nath Bhanjan-275101, India.

Submitted: April 15, 2010; Returned to authors for corrections: April 21, 2010; Approved: August 28, 2010.

\begin{abstract}
Nine different receptacles were tested with the MPN method to determine which receptacle was most reliable and economical for MPN counts. Results showed that 96 well PCR plate were the best vessels for this type of analysis and facilitated the isolation of viable Methylotrophs.
\end{abstract}

Key words: Methylotrophs, MPN, Receptacle

Ecological studies on abundance and diversity of Methylotrophs in soil, water, plant and animal surfaces are often hampered by problems in enumeration through standard most probable number (MPN) technique. Besides the need for a lot of space, glassware, and media, the standard MPN method is tedious in its operation and prone to erroneous results. Errors are due to the limited surface area for colony formation in test tubes. Moreover, this technique requires additional purification step to isolate pure cultures of Methylotrophs. Other enumeration techniques employ selective enumeration or indirect methods such as fluorescent microscopy, serological methods (6) and isotope labeling (4). Methods based on stable carbon isotope labeling have been recommended (5) by various workers in soil core studies in fields (1). They have extended this to biomass estimation. Vorodev and Dedysh (7) emphasized the combination of direct fluorescent in situ hybridization (FISH) counts for Peat soil Methanotrophs (a subset of Methylotrophs) and 4'-6-Diamidino-2-phenylindole (DAPI) staining for determining the cell count. That noted, MPN is routinely used for enumeration of Methylotrophs (2). In this investigation, several different receptacles, such as polymerase chain reaction (PCR) plates, enzymes linked immune sorbent assay (ELISA) plates, porcelain cavity tiles and Petri plates in combination with the soil dilution using alginate and agar as a gel matrix were tested. The objective was to reduce the time, cost for simultaneous enumeration of a large number of samples. The soil samples were collected from 0-10 $\mathrm{cm}$ depth from cultivated agricultural fields of Directorate of Seed Research, Kusmaur, Mau, India. The samples were air dried and passed through $2 \mathrm{~mm}$ sieve before processing it for enumeration. A $10 \mathrm{X}$ dilution series in nitrate mineral salt (NMS) medium (3) supplemented with methanol $(0.5 \%)$ and Cyclohexamide $\left(50 \mu \mathrm{g} \mathrm{mL}^{-1}\right)$ were prepared. Initial dilution was used after thorough and constant stirring, using gyratory shaker (60 revolutions $\min ^{-1}, 4^{\circ} \mathrm{C}, 24 \mathrm{~h}$ ) facilitating the disintegration of large size particles and homogenous mixing of soil in medium.

The methodology varied with the choice of receptacle which included: ELISA plates, PCR plates, PCR plate lids, porcelain cavity tiles, Plastic Cryo Vials, Eppendorf tubes, and Petri dishes. Appropriate dilutions were seeded with $1 \%$ agar based NMS medium and were used in different receptacles for enumeration. For Petri dishes, each dilution was placed either in wells cut out from $1.5 \%$ water agar plates or as immobilized

*Corresponding Author. Mailing address: National Bureau of Agriculturally Important Microorganisms (ICAR), Kusmaur, Kaithauli, Mau Nath Bhanjan275101, India.; E-mail: sudhanshukshyp@gmail.com 
agar /calcium alginate macro beads (5) on the surface of $1.5 \%$ agar plates. A minimum of three replicates, were maintained for each dilution and the reproducibility was determined by repeating the experiments. All titer plates and tubes were sealed with breathable sealing tape-400S (Axygen Scientific) and incubated at $28 \pm 2^{\circ} \mathrm{C}$. Since a key problem in the study of Methylotrophic bacteria is their enumeration and subsequent isolation. Most of the studies to date have employed cultural dilutions, involving large amounts of glassware for enumeration of Metylotrophs considered to be being too laborious. Also scoring sometimes takes a very long time for samples having very low populations, especially when many different forms exist. Earlier studies as environmental variation of Methylotrophs using culture dilution and MPN standard protocols have failed to provide reliable and accurate count. However, for studies in which the enumeration is of great significance in understanding the fertility status of soil the MPN technique need to be more precise and modified to accommodate the isolation of Methylotrophs. This offers an improvement to existing method. Comparisons of results are presented in Table1. The 96 well PCR plate $(300 \mu \mathrm{L}$ well capacities) system was the best receptacle studied as it allowed for growth and enumeration more uniformly over 5-6 weeks. PCR and/or ELISA plates with 30 -or $50 \mu \mathrm{l}$ capacity were not suitable as the medium gradually dries up making isolation impossible.

Table 1. Differential evaluation of modifications of MPN techniques for Methylotrophs.

\begin{tabular}{|c|c|c|c|c|c|c|c|}
\hline Types of Cosmos & $\begin{array}{c}\text { Capacity of } \\
\text { Cavity / Tubes } \\
\mu \mathbf{L}\end{array}$ & $\begin{array}{c}\text { Number of } \\
\text { samples/unit }\end{array}$ & $\begin{array}{c}\text { Duration of } \\
\text { Incubation } \\
\text { days } \\
\end{array}$ & $\begin{array}{l}\text { Glassware/ } \\
\text { Plastic ware }\end{array}$ & $\begin{array}{l}\text { Quantity of } \\
\text { Media a mL }\end{array}$ & $\begin{array}{c}\text { Space } \\
\text { requirement a } \\
\text { mm } \\
\end{array}$ & $\begin{array}{l}\text { MPN x } 10^{7} \\
g^{-1} \text { dry soil }\end{array}$ \\
\hline $\begin{array}{l}\text { PCR/ ELISA Plates with } \\
300 \mu \mathrm{L} \text { cavities/well }\end{array}$ & 300 & 96 & $10-15$ & 1 plate & 9 & $80 \times 120$ & 4.61 \\
\hline $\begin{array}{l}\text { PCR/ ELISA Plates with } \\
50 \mu \mathrm{L} \text { cavities/well }\end{array}$ & 50 & 96 & $10-15$ & 1 plate & 105 & $80 x 120$ & 4.62 \\
\hline $\begin{array}{l}\text { Plastic PCR Plate lids with } \\
30 \mu \mathrm{L} \text { cavities }\end{array}$ & 30 & 96 & 15 & 1 plate & 105 & $80 \times 120$ & 4.58 \\
\hline Porcelain cavity tiles & 500 & $10-12$ & 15 & 3 tiles & 1.5 & $110 \times 90$ & 4.62 \\
\hline $\begin{array}{l}1 \% \text { bacterial beads on } \\
1.5 \% \text { agar base }\end{array}$ & $\sim 50$ & 10 & $12-15$ & 3 petri dishes & 1.5 & $100 \times 100 \times 30$ & 4.82 \\
\hline $\begin{array}{l}1 \% \text { bacterial beads in wells } \\
\text { of } 1.5 \% \text { agar base }\end{array}$ & $\sim 50$ & 10 & $12-15$ & 3 petri dishes & 1.5 & $100 \times 100 \times 30$ & 4.61 \\
\hline $\begin{array}{l}1 \% \text { bacterial calcium } \\
\text { alginate beads in wells of } \\
1.5 \% \text { agar base }\end{array}$ & $\sim 50$ & 6 & $10-12$ & 3 petri dishes & 1.5 & $100 \times 100 \times 30$ & 4.62 \\
\hline Plastics Cryo Vials & 2000 & 1 & $12-15$ & 50 vials & 150 & $300 \times 150$ & 4.62 \\
\hline Eppendorf Tubes & 1500 & 1 & $12-15$ & 50 vials & 150 & $290 \times 90$ & 4.62 \\
\hline $\begin{array}{l}\text { Glass test tubes } \\
150 \times 15 \mathrm{~mm} b\end{array}$ & $10 \mathrm{~mL}$ & 1 & $12-15$ & 50 test tubes & $500^{c}$ & $300 \times 150$ & 4.62 \\
\hline
\end{tabular}

${ }^{\mathrm{a}}$ for a set of 3 replicates 10 dilutions; ${ }^{\mathrm{b}}$ Standard protocol; ${ }^{\mathrm{c}}$ Basket with 53 tubes. 
Use of a porcelain cavity tile appears to be good, but due to greater exposed surface area, drying up of the agar and alginate was very rapid. Moreover, since each tile has only 12 cavities, a minimum of three tiles were required for one sample. The use of agar/alginate macro beads impregnated on $1.5 \%$ agar base or in wells also allowed scoring within 10-15 days. Beads with the soil dilutions frequently led to overlapping of colonies and the process of beads preparation/impregnation itself required skills and precision. Although a minimum of multiple petri-dishes were required for evaluating at least one sample, scoring was easy. Comparing all these receptacles, the standard protocols using test tube based MPN required more space, media (>50X) and glassware, besides scoring up to after 10-15 days only. The array of techniques developed and tested in this paper facilitated the isolation of Methylotrophs, due to immobilization of Methylotrophic colonies in a gel matrix. Hence, these novel techniques exploited the replication aspect of the MPN techniques, there by using the MPN principle but enhancing its sensitivity and cost effectiveness by using 96-well PCR plates and agar based immobilization system. This was highly significant as it simplifies Methylotrophic isolation and enumeration concurrently from one experimental setup within 10-12 days of incubation, besides cutting the cost on space, media and glassware. Regardless of which receptacle was selected, the simplicity and rapidity of the method proved advantageous for counting. It remains to be determined whether the method is compatibility for enumeration of other important microbial groups from same or different sources simultaneously by changing the nutritional medium and incubation conditions. The use of PCR plates was sensitive, cost- and time -effective. This novel technique, without loss in viability for 6-8 weeks, may also be employed for isolation of
Methylotrophic colonies that are immobilized in the gel matrix and storage of samples at room temperature. In addition, it can aid in processing many of samples with ease, beside extension, may be extended for enumeration of other microorganisms from diverse sources.

\section{ACKNOWLEDGEMENTS}

The grant supported the study from Application of Microbes in Agriculture and Allied Sectors (AMAAS) Network Project, Indian Council of Agricultural Research, New Delhi, India. Infrastructure facility and encouragement by Director of NBAIM is, duly acknowledged.

\section{REFERENCES}

1. Buckley, D.H.; Huangyutitham, V.; Hsu, S-F.; Nelson, T.A. (2007). Stable Isotope Probing with $15 \mathrm{~N} 2$ Revels novel Noncultivation Diazotrophis in soil. Appl. Environ. Microbiol.73:3196-3204.

2. Escoffier, S.; Le Mer, J.; Roger, P.A. (1997). Enumeration of methanotrophic bacteria in rice field soils by plating and MPN technique: a critical approach. Eur. J Soil Biol. 33:41-51

3. Hanson, R.S. (1998). Ecology of methylotrophic bacteria. In techniques in Microbial Ecology (Burlage et al., eds), pp. 137-162. Oxford Univ. Press, New York

4. McDonald, I.R.; Radajewski, S.; Murrell, J.C. (2005). Stable isotope probing of nucleic acids in Methanotrophs and Methylotrophs: A review. Org. Geochem. 36:779-787.

5. Slobodova, N.V.; Kolganova, T.V.; Bulvgina, E.S.; Kuznetsov, B.B.; Turova, T.P.; Kravchenko, I.K. (2006). Comparative characterization of cultured methane-oxidizing bacteria by serological and molecular methods. Mikrobiol. 75: 397-403.

6. Sung-In,Y.; Young-Kyoo, C.; Byung-Chan, L. (2003). Effective bead preparation of coimmobilized methanogenic and methanotrophic bacteria for tetrachloroethene degradation. Biodegrad. 14: 347-355.

7. Vorobev, A.V.; Dedysh, S.N. (2008). Inadequacy of Enrichment Culture Technique for Assessing the Structure of Methanotrophic Community in Peat soil. Mikrobiol. 77: 504-507. 